\title{
Portals of entry for salmonid whirling disease in rainbow trout
}

\author{
Maria E. Markiw \\ US Fish and Wildlife Service, National Fish Health Research Laboratory, Box 700, Kearneysville, West Virginia 25430, USA
}

\begin{abstract}
Portals of entry via the skin, fins, buccal cavity and digestive tract have been demonstrated for the myxozoan that causes salmonid whirling disease. Experimentally, young rainbow trout Salmo gairdneri were exposed to triactinomyxon spores. Within 10 min after initial exposure, intracellular aggregates of triactinomyxon sporoplasms appeared in the epithelia of exposed fish. During several hours following penetration, the sporoplasms moved or were transported from the external epithelial layers into deeper strata. Unexposed control trout were free of the organism. The aggregates of intracellular triactinomyxon sporoplasms were identified serologically as being Myxobolus cerebralis.
\end{abstract}

\section{INTRODUCTION}

Whirling disease is a chronic parasitic infection that affects salmonid fishes of all ages (Markiw 1986a). The disease caused by the myxozoan Myxobolus (Myxosoma) cerebralis was reported first by Hofer in 1903 , who described 8 to $9 \mu \mathrm{m}$ spores in the cartilage of young salmonids afflicted with what he termed Drehkrankheit. For most of the subsequent 80 yr, the causative agent or initiator of whirling disease was widely throught to be the aged spores of $M$. cerebralis (Uspenskaya 1978, Hoffman \& Putz 1969); however, such infectivity or causal role has not been demonstrated. Markiw \& Wolf (1983) and Wolf \& Markiw (1984) demonstrated that the causative myxozoan has a 2-host life cycle involving fish and aquatic tubificid oligochaete. Two separate stages of sporogeny occur in each host. The myxosporean $M$. cerebralis produced in fish is a pathogen that infects a tubificid worm and transforms into an actinosporean triactinomyxon which then infects salmonids and initiates whirling disease. Antigenic homology of the 2 morphologically distinct spore forms has been demonstrated serologically (Markiw 1985).

Salmonids contract whirling disease in 2 ways: by ingesting tubificids that harbor the specific actinosporean triactinomyxon, and by brief contact with waterborne triactinomyxons released from infected tubificids. How, in what form, and where in a fish the infectivity begins has long been a matter of speculation. This report describes and illustrates portals of entry for whirling disease infectivity and the appearance of initial forms in trout.

\section{MATERIALS AND METHODS}

Three different populations of triactinomyxons were used, propagated in 1983,1985 , and 1986 by the methods described previously (Wolf \& Markiw 1984, Markiw 1986). Each time, stock of actinosporean-free tubificids collected at trout hatchery were exposed to viable spores of Myxobolus cerebralis and maintained in flowing springwater at 12 to $13^{\circ} \mathrm{C}$. As noted by Markiw \& Wolf (1983) the natural populations of tubificids used in this study consisted of 4 genera: Tubifex tubifex, llyodrilus tempeltoni, Limnodrilus hoffmeisteri, and Quistadrilus multisetosus. Tubifex tubifex (Müller) was identified as specific intermediate host (Wolf et al. 1986).

Waterborne triactinomyxons released by the experimentally-infected tubificids were harvested from the effluent on a $50 \mu \mathrm{m}$ mesh screen. In each of 3 trials, 200 healthy, 2-wk-old rainbow trout Salmo gairdneri were held in $1 \mathrm{l}$ screen compartments that retained triactinomyxons but permitted a constant flow of springwater. The population of 1 or $2 \mathrm{~d}$ collections used as the infective dose was calculated to contain about 2 million triactinomyxons. The trout were exposed for $1 \mathrm{~h}$ and were then transferred to holding containers supplied with springwater. Twelve fish were taken at 10,30, and $60 \mathrm{~min}$; at 2, 4, 8, and $16 \mathrm{~h}$; then daily for $6 \mathrm{~d}$. Specimen 
trout were fixed in $10 \%$ phosphate-buffered neutral formalin. Samples of triactinomyxons retained on screens for exposures were also taken and fixed for microscopic examination; just before the fish were placed in the exposure compartments and again 5 min after triactinomyxons were in contact with fish. In a 4 th trial, 200 fish were placed directly into an aquarium that contained infected tubificids, and held continuously for $6 \mathrm{~d}$. Time-course samples, each of 12 fish, were removed in a similar schedule and processed as above. Unexposed fish from the same populations served as negative controls. Some trout (the survivors from each trial) were held for 4 to $5 \mathrm{mo}$ and then examined for the presence of Myxobolus cerebralis spores.

Wet mounts of tins or skin tissues were stained with Giemsa. Paraffin-blocked histological sections, $4 \mu \mathrm{m}$ thick, were stained with May-Grünwald Giemsa. Preparations were examined by light microscopy (100 or $430 \times$ magnification).

Serological tests were used to identify specific shared antigens between the triactinomyxons used for exposure of the fish and the first intracellular forms found in fish epithelia after exposure. The direct fluorescent antibody test was conducted by using anti-Myxobolus cerebralis and anti-triactinomyxon conjugates, prepared as described elsewhere (Markiw \& Wolf 1978, Markiw 1985). Preparations were examined by fluorescence microscopy under oil $(970 \times$ magnification). Indirect enzyme-linked immunoperoxidase staining was done using the method described by Bourne (1983). Anti-triactinomyxon unconjugated rabbit serum (at 1:80 dilution) or anti- $M$. cerebralis serum (at 1:20 dilution) was used as the primary antibody and goat anti-rabbit IgG $(\mathrm{H}-\mathrm{L})$ horseradish peroxidase conjugate at $1: 40$ dilution as the secondary antibody. Hanker-
Yates substrate solution was used to strain specific antigens and colored sporoplasms greenish-blue or blue and nuclei black.

\section{RESULTS}

In all trials, trout exposed to the actinosporean triactinomyxon showed aggregates of small $(1.5$ to $2 \mu \mathrm{m})$ intracellular forms in the epithelium of the fins, skin. and buccal cavity (particularly at the base of gills) and in the upper esophagus and lining of the digestive tract. As little as $10 \mathrm{~min}$ of exposure was sufficient to allow penetration of the epithelium (Figs. 1 and 2). Observed intracellular forms were the same size as sporoplasms of triactinomyxons and were serologically identified by the direct fluorescent antibody test and immunoperoxidase staining as being Myxobolus rerebralis. In all trials, unexposed corresponding control trout were free of the organism.

Individual forms of aggregates of sporoplasms (average 12 to $18 \mu \mathrm{m}$ in size) were ovoid, round, or pyriform and were found most frequently $30 \mathrm{~min}$ after exposure to triactinomyxons. They contained various numbers of sporoplasms most often from 20 to over 50 but sometimes only a few or even 1 , were observed. The peak of infection was evident in the outer epithelium 2 to $4 \mathrm{~h}$ after exposure (Fig. 2C, D, E); thereafter the sporoplasms rapidly moved or were transported into deeper strata. Aggregates were no longer evident after $8 \mathrm{~h}$ and after $24 \mathrm{~h}$ only single sporoplasms or groupings of 2 or 3 were recognizable scattered in deeper epithelial layers.

Microscopic examination of triactinomyxons taken before and 5 min after fish were exposed showed about $60 \%$ of the triactinomyxons had released sporoplasms while being in contact with fish; those that were not in

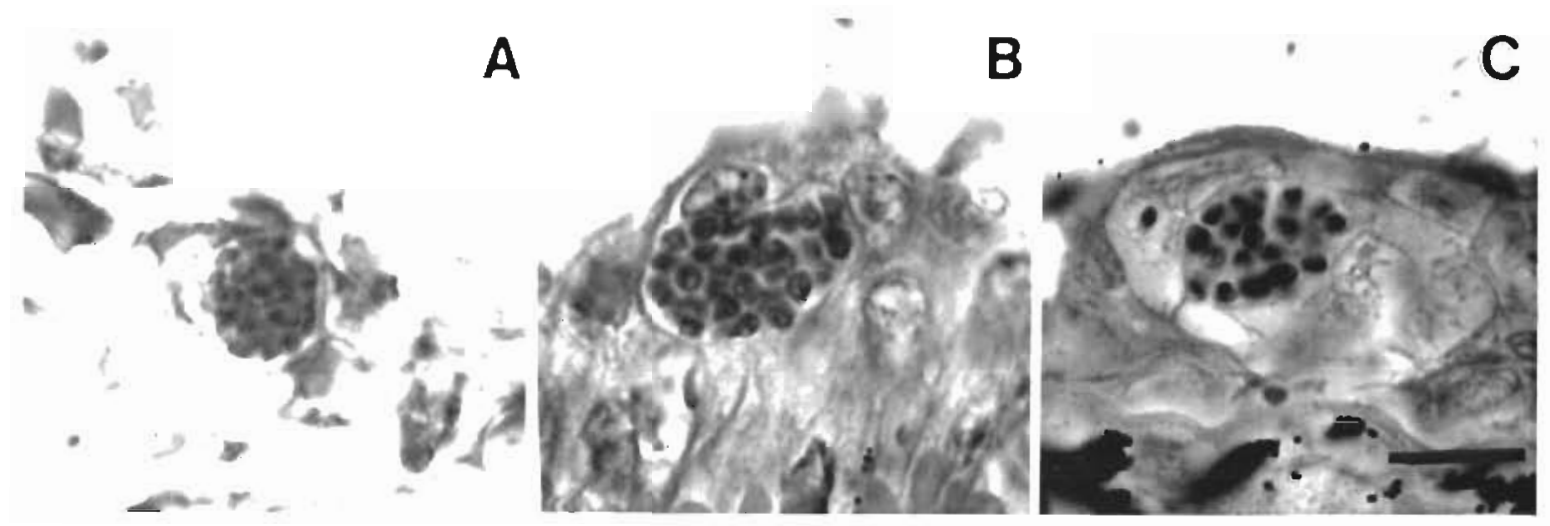

Fig. 1. Myxobolus cerebralis initial forms of whirling disease infection in tissue sections of rainbow trout Salmo gairdneri, stained with May-Grünald Giemsa. (A) Compact aggregate of sporoplasms in epithelial cell at base of caudal fin, 10 min after exposure to triactinomyxons. (B) Two overlapping epithelial cells at the base of the caudal fin with intracellular inclusions of dark stained sporoplasms, some on left showing first stage of mitosis, 10 min after exposure. (C) Intracellular inclusion of sporoplasms in dorsal epithelium, showing secondary cell (middle left side) in. mitosis, and the host cell nucleus compressed to left side, 30 min after exposure. Bar $=10 \mu \mathrm{m}$ 


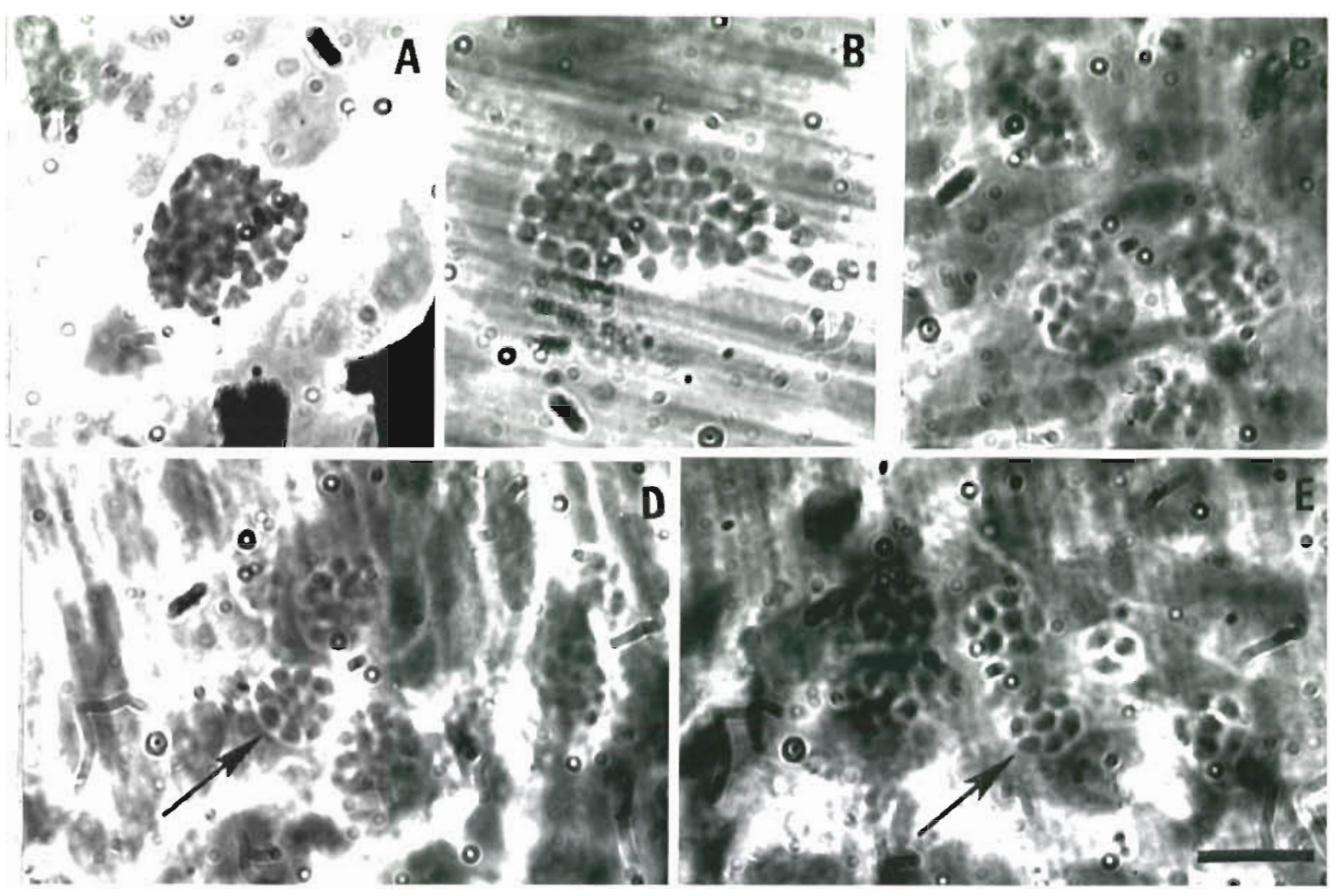

Fig. 2. Myxobolus cerebralis initial forms in wet mounts of fins stained with Giemsa. (A) Aggregates of sporoplasms, 10 min and (B) $30 \mathrm{~min}$ after exposure to triactinomyxons in the distal portion of caudal fins. (C) Appearance of numerous groups of aggregated sporoplasms, $2 \mathrm{~h}$ after initial exposure and $(D, E)$ at $4 \mathrm{~h}$; arrows point to rosette-like cells with various number of internal cells, suggesting radial segmentation. Bar $=10 \mu \mathrm{m}$

contact with fish remained intact. Aggregates of sporoplasms were then observed as intracellular inclusions among the epithelial cells of host fish tissue. The triactinomyxons with missing sporoplasms also had empty polar capsules and missing nuclei beneath them.

Fish held in aquarium with infected tubificids and exposed to low concentration of waterborne triactinomyxons showed aggregates of sporoplasms in wet mounts of fins for $6 \mathrm{~d}$. However, examinations of tissue sections failed to detect infectivity in about $40 \%$ of the fish. All exposed fish (whether to waterborne triactinomyxons or to infected tubificids) that survived from each exposure developed Myxobolus cerebralis spores in 4 to 5 mo. All unexposed corresponding control fish were free of $M$. cerebralis spores.

\section{DISCUSSION}

This study demonstrated 2 critical factors for detection of the initial stage of salmonid whirling disease in fish. First, high concentrations of triactinomyxons must be present; and second, microscopic examinations of exposed trout should be conducted within a short time after exposure to infectivity.
It has been previously demonstrated that the actinosporean triactinomyxon spore stage initiates whirling disease (Wolf \& Markiw 1984). The present study further corroborates those findings. In addition, it shows that the aggregates of sporoplasms embedded in epithelial cells of fish shortly after exposure of the fish to triactinomyxons were indeed derived from triactinomyxons. However, the transfer mechanism and the role of the polar capsule-filaments remain unexplained.

The findings also relate to work described by Daniels et al. (1976), who found similar forms in epihelia of fish exposed to undefined infective agents for whirling disease, but did not establish a relation to actual disease. In both that study and the present study fish were exposed to whirling disease infectivity. The findings, therefore, strongly suggest that the observed organisms were identical.

The discovery of multiple routes of entry for the infective stage of whirling disease and the identification of the primary sites of infection further extend our understanding of the life cycle of Myxobolus cerebralis.

Acknowledgement. I thank D. Bowling for histological preparations. 


\section{LITERATURE CITED}

Bourne, J. A. (1983). Handbook of immunoperoxidase staining methods. Immunochemistry Laboratory, DACO Corporation, Santa Barbara, California

Daniels, S. B., Herman, R. L., Burke, C. N. (1976). Fine structure of an unidentified protozoan in the epithelium of rainbow trout exposed to water with Myxosoma cerebralis J. Protozool. 23: 402-410

Hofer, B. (1903). Über die Drehkrankheit der Regenbogenforelle. Allg. Fisch. Ztg XXVIII, 1; 7-8

Hoffman, G. L., Putz, R. E. (1969). Host susceptibility and the effect of aging, freezing, heat, and chemicals on spores of Myxosoma cerebralis. Prog. Fish. Cult. 31: 35-37

Markiw, M. E. (1985). Salmonid whirling disease: serological cross-reactivity confirms myxosporidan-actinosporean unity. U.S. Fish and Wildlife Service, Research Information Bulletin 85-74.1 p

Markw, M. E. (1986a). Aduit trout can becone infected with whirling disease. U.S. Fish and Wildlife Service, Research Information Bulletin 13-86. 2 p.
Markiw, M. E. (1986b). Salmonid whirling disease: dynamics of experimental production of the infective stage the triactinomyxon spore. Can. J. Fish. Aquat. Sci. 43: 521-526

Markiw, M. E., Wolf, K. (1978). Myxosoma cerebralis: fluorescent antibody techniques for antigen recognition. J. Fish. Res. Bd Can. 35: 828-832

Markiw, M. E., Wolf, K. (1983). Myxosoma cerebralis (Myxozoa: Myxosporeal etiologic agent of salmonid whirling disease requires tubificed worm (Annelida: Olıgochaeta) in its life cycle. J. Protozool. 30: 561-564

Uspenskaya, A. V. (1978). Study conducted during 1954-1955. Biological peculiarities of the spore stage of Myxosoma cerebralis (Myxosporida: Myxosomatidae). Parasitologiya 12: 15-20 (Russian; English summary)

Wolf, K., Markiw, M. E. (1984). Biology contravenes taxonomy in the Myxozoa: new discoveries show alternation of the invertebrate and vertebrate hosts. Science 225: 1449-1452

Wolt, K., Markiw, M. E., Hiltunen, J. K. (1986). Salmonid whiring disease: Tubifex tubifex (Mülier) identıfied as the essential oligochaete in the protozoan life cycle. J. Fish. Dis. 9: $83-85$ 